Тарасенко В. С., кандидат юридичних наук, доцент кафедри трудового права та права соиіального забезпечення Національного університету "Одеська юридична академія"

\title{
ПРОБЛЕМИ ЗАБЕЗПЕЧЕННЯ НАЛЕЖНОГО СОЦІАЛЬНОГО ЗАХИСТУ ВЕТЕРАНІВ ВІЙНИ
}

\begin{abstract}
Анотація. Стаття присвячена дослідженню законодавства, що запроваджує зміну механізму реалізації права ветеранів війни на соціальний захист. Аналізується відповідність цих положень нормам Конституції України та рішенням Конституційного Суду України щодо неприпустимості внесення довільних змін до наявної системи норм, недопущення звуження змісту й обсягу наявних прав і свобод, забезпечення права кожного на достатній життєвий рівень для себе і своєї сім'ї.

Ключові слова: соціальний захист, право на соціальний захист, ветерани війни, звуження обсягу прав і свобод.
\end{abstract}

Постановка проблеми. 28 грудня 2014 року Законом України «Про внесення змін до Бюджетного кодексу України щодо реформи міжбюджетних відносин» були внесені зміни до Бюджетного кодексу України, зокрема розділ VI «Прикінцеві та перехідні положення» доповнено пунктом 26, яким передбачено, зокрема, що норми і положення статей $12,13,14$, 15 та 16 Закону України «Про статус ветеранів війни, гарантії їх соціального захисту» застосовуються у порядку та розмірах, встановлених Кабінетом Міністрів України, виходячи з наявних фінансових ресурсів державного і місцевого бюджетів та бюджетів фондів загальнообов' язкового державного соціального страхування [1].

Метою статті $€$ аналіз законодавства, що запроваджує зміну механізму реалізації права ветеранів війни на соціальний захист.

Виклад основного матеріалу дослідження. На наш погляд, не можна погодитися зі зміною механізму реалізації права громадян на соціальний захист, який запроваджений зазначеним вище Законом України, виходячи з такого.

Відповідно до статті 75 Конституції України Верховна Рада України є єдиним органом законодавчої влади в Україні. Статтею 85 Конституції України до виключних повноважень Верховної Ради України належить прийняття законів [2, ст. 85]. Це означає, що жоден інший орган державної влади не уповноважений приймати закони. Однак, прийнявши пункт 26 розділу VI «Прикінцеві та перехідні положення» Бюджетного кодексу України, Верховна Рада України тим самим делегувала свої повноваження Кабінету Міністрів України, надавши йому право самостійно вирішувати питання надання пільг та гарантій різним категоріям осіб, зокрема ветеранам війни. Такий підхід $€$ неприпустимим і суперечить частині другій статті 6, частині другій статті 19, статті 75 Конституції України.

Про неможливість передачі повноважень Верховної Ради України іншим органам чи посадовим особам уже неодноразово зазначав Конституційний Суд України у своїх рішеннях від 14 грудня 2000 року № 15-рп/2000 та від 08 липня 2016 року № 5-рп/2016.
Відповідно до статті 3 Закону України «Про Кабінет Міністрів України» Кабінет Міністрів України здійснює виконавчу владу на підставі, в межах повноважень та у спосіб, що передбачені Конституцією України та законами України.

Таким чином, Верховною Радою України та Кабінетом Міністрів України порушуються конституційні принципи, закріплені в частині 2 статті 6, частині другій статті 19, пункті 1 частини першої статті 92 Конституції України.

Відповідно до частини першої статті 8 Конституції України в Україні визнається і діє принцип верховенства права. Конституційний Суд України в абзаці другому підпункту 4.1 пункту 4 мотивувальної частини рішення від 2.11.2004 року № 15-рп/2004 зазначив, що верховенство права

вимагає від держави його втілення у правотворчу та правозастосовну діяльність, зокрема у закони, які за своїм змістом мають бути проникнуті передусім ідеями соціальної справедливості, свободи, рівності тощо [3].

Одним із елементів верховенства права $€$ принцип правової визначеності, у якому стверджується, що обмеження основних прав

людини та громадянина і втілення цих обмежень на практиці допустиме лише за умови забезпечення передбачуваності застосування правових норм, встановлюваних такими обмеженнями. Тобто обмеження будь-якого права має базуватися на критеріях, які дадуть змогу особі відокремлювати правомірну поведінку від протиправної, передбачати юридичні наслідки своєї поведінки.

Із цього приводу Конституційний Суд України у своїх рішеннях неодноразово наголошував на тому, що принцип правової визначеності вимагає ясності й однозначності правової норми та забезпечення того, щоб ситуації й правовідносини залишалися передбачуваними. Громадяни мають бути впевненими у своїх законних очікуваннях, що набуте ними на підставі чинного законодавства право, його зміст та обсяг буде ними реалізовано, тобто набуте право не може бути скасоване, звужене (правові позиції Конституційного Суду України в таких рішеннях: від 22 вересня 2005 року № 5-рп/2005, від 29 червня 2010 року № 17-рп/2010, від 22 грудня 2010 року № 23-рп/2010, від 11 жовтня 2011 року № 10-рп/2011).

Стабільність правового регулювання проявлясться, зокрема, у неприпустимості внесення довільних змін до наявної системи норм та $€$ віддзеркаленням підтримання довіри громадян до законів та дій держави. Збереження розумної стабільності означає серед іншого обов'язок законодавця у разі зміни умов набуття права на отримання соціальних благ враховувати законні очікування, пов'язані з виконанням (повністю або частково) умов набуття такого права.

Забезпечення верховенства права має враховуватися законодавцем і у разі внесення змін до законів, при цьому необ- 
хідно насамперед забезпечувати недопустимість звуження змісту й обсягу наявних прав і свобод, що передбачено статтею 22 Конституції України.

Питання недопущення звуження змісту й обсягу наявних прав і свобод неодноразово було предметом конституційного розгляду. Зокрема, у абзаці шостому пункту 4 рішення Конституційного Суду України від 14.06.2007 року 3-рп/2007 зазначається, що звуження змісту прав і свобод означає зменшення ознак, змістовних характеристик можливостей людини, які відображаються відповідними правами та свободами, тобто якісних характеристик права [4]. Звуження обсягу прав і свобод - це зменшення розміру або кількості благ чи будь-яких інших кількісно вимірюваних показників використання прав і свобод, тобто їх кількісної характеристики.

Конституційний Суд України в рішенні № 9-рп/2009 від 28 квітня 2009 року, вказуючи на недопустимість звуження змісту й обсягу наявних прав і свобод, що об'єктивно призведе до погіршення становища особи в суспільстві через їх обмеження, зробив концептуальне застереження органам державної влади про те, що невиконання державою своїх соціальних зобов'язань щодо окремої категорії осіб призводить до порушення принципів соціальної, правової держави, ставить громадян у нерівні умови, підриває принцип довіри особи до держави (абзац п’ятий пункту 5 мотивувальної частини) [5].

У своєму рішенні від 20 березня 2002 року № 5-рп/2002 Конституційний Суд України визначив, що Конституція України відокремлює категорії громадян України, які потребують додаткових гарантій держави, зокрема гарантій соціального захисту [6]. До них насамперед належать громадяни, які відповідно до статті 17 Конституції України перебувають на службі у військових формуваннях та правоохоронних органах, забезпечуючи суверенітет і територіальну цілісність України, її економічну та інформаційну безпеку. Зупинення пільг, компенсацій і гарантій для зазначених категорій громадян без відповідної матеріальної компенсації $€$ порушенням гарантованого державою права на їх соціальний захист та членів їхніх сімей. Отже, військовослужбовці як під час проходження служби, так і після іiї закінчення $€$ окремою категорією громадян України, що потребують додаткових гарантій соціального захисту з боку держави.

Відповідно до ст. 4 Закону України «Про статус ветеранів війни, гарантії їх соціального захисту» ветеранами війни $€$ особи, які брали участь у захисті Батьківщини чи в бойових діях на території інших держав [7, ст. 4]. До ветеранів війни належать: учасники бойових дій, особи з інвалідністю внаслідок війни, учасники війни. Статтею 10 зазначеного Закону визначено також осіб, на яких поширюється чинність цього Закону, - сім'ї військовослужбовців, сім’ї осіб, які загинули або померли внаслідок поранення, контузії, каліцтва або захворювання, одержаних під час участі в антитерористичній операції, захищаючи незалежність, суверенітет та територіальну цілісність України.

У рішенні Конституційного Суду України від 01 грудня 2004 року № 20-рп/2004 зазначається, що на осіб, які за Законом України «Про статус ветеранів війни, гарантії їх соціального захисту» належать до ветеранів війни, мають поширюватись гарантії державного соціального захисту відповідно до положень частини п’ятої статті 17 Конституції України [8]. Отже, положення Закону України «Про статус ветеранів війни, гарантії їх соціального захисту» поширюються на осіб, які безпосередньо брали участь у захисті Батьківщини, іiі незалежності та територіальної цілісності, а також на членів їхніх сімей.

Україна як соціальна держава взяла на себе зобов'язання щодо соціального захисту громадян, забезпечення права кожного на достатній життєвий рівень для себе і своєї сім’' тощо. Надання матеріального забезпечення та пільг ветеранам війни залежно від наявних фінансових ресурсів державного і місцевого бюджетів та фондів загальнообов'язкового державного соціального страхування означає не лише суттєве обмеження їх прав, звуження їх змісту та обсягу, а й дискримінацію таких осіб, приниження людини, зневажання іiі честі й гідності, повагу до яких закріплено на законодавчому рівні.

Відповідно до статті 48 Конституції України кожен має право на достатній життєвий рівень для себе і своєї сім’ї, що включає достатнє харчування, одяг, житло. Зазначене право належить до найважливіших конституційних соціальних прав людини і громадянина.

Положення статті 48 Конституції України повністю відтворюють вимоги статті 11 Міжнародного пакту про економічні, соціальні та культурні права 1966 року, згідно з якою право кожного на достатній життєвий рівень для нього і його сім’і включає достатнє харчування, одяг і житло. Ратифікувавши цей Пакт у 1973 році, Україна визнала право на достатній життєвий рівень, взяла на себе відповідальність за його забезпечення і тому має вживати належних заходів щодо забезпечення здійснення цього права.

Законодавець, змінюючи чинне законодавство в сфері соціального захисту громадян, зокрема ветеранів війни, має балансувати між необхідністю змін у законодавчому регулюванні та збереженням стабільності в суспільстві, при цьому слід визнавати першочерговими інтереси громадян, які здійснюють професійні обов'язки, пов'язані з підвищеним ризиком для життя і здоров'я.

На підтвердження вищевикладеного є підстави вважати, що положення пункту 26 розділу VI «Прикінцеві та перехідні положення» Бюджетного кодексу України в частині, за якою положення статей 12, 13, 14, 15 та 16 Закону України «Про статус ветеранів війни, гарантії їх соціального захисту» застосовуються у порядку та розмірах, встановлених Кабінетом Міністрів України, виходячи з наявних фінансових ресурсів державного і місцевого бюджетів та фондів загальнообов'язкового державного соціального страхування, не відповідає статті 1 , частині другій статті 3 , статті 6 , частинам першій, другій статті 8, частині другій статті 19, частині третій статті 22, пункту 14 частини першої статті 92 Конституції України, у зв'язку 3 чим може бути визнане неконституційним.

Висновки. Таким чином, у статті проаналізовано законодавство, яке запроваджує зміну механізму реалізації права ветеранів війни на соціальний захист, а також відповідність законодавчих положень нормам Конституції України та рішенням Конституційного Суду України щодо неприпустимості внесення довільних змін до наявної системи норм, недопущення звуження змісту й обсягу наявних прав і свобод, забезпечення права кожного на достатній життєвий рівень для себе і своєї сім’і. 


\section{Лimepamypa:}

1. Про внесення змін до Бюджетного кодексу України щодо реформи міжбюджетних відносин: Закон України від 28.12.2014 року № 79-VIII. Відомості Верховної Ради України. 2015. № 12. Ст. 76.

2. Конституція України від 28.06.1996 року № 254к/96-ВР. Відомості Верховної Ради України. 1996. № 30. Ст. 141.

3. Рішення Конституційного Суду України від 2 листопада 2004 року № 15-рп/2004 (справа про призначення судом більш м'якого покарання). Офіційний вісник України. 2004. № 45. Ст. 2975.

4. Рішення Конституційного Суду України від 14 червня 2007 року № 3-рп/2007 (справа про перерахунок пенсій військовослужбовців). Офіційний вісник України. 2007. № 48. Ст. 1990.

5. Рішення Конституційного Суду України від 28 квітня 2009 року № 9-рп/2009 (справа про допомогу по безробіттю звільненим за угодою сторін). Офіційний вісник України. 2009. № 35. Ст. 1210.

6. Рішення Конституційного Суду України від 20 березня 2002 року № 5-рп/2002 (справа щодо пільг, компенсацій і гарантій). Офіційний вісник України. 2002. № 13. Ст. 669.

7. Про статус ветеранів війни, гарантії їх соціального захисту: Закон України від 22 жовтня 1993 № 3551-XII. Відомості Верховної Ради України. 1993. № 45. Ст. 425.

8. Рішення Конституційного Суду України від 01 грудня 2004 року № 20-рп/2004 (справа про зупинення дії або обмеження пільг, компенсацій і гарантій). Офіційний вісник України. 2004. № 50. Ст. 3289.

Тарасенко В. С. Проблемы обеспечения надлежащей социальной защиты ветеранов войны

Аннотация. Статья посвящена исследованию законодательства, которым внедрено изменение механиз- ма реализации права ветеранов войны на социальную защиту. Анализируется соответствие данных положений нормам Конституции Украины и решениям Конституционного Суда Украины относительно недопустимости внесения произвольных изменений в имеющуюся систему норм, недопущения сужения содержания и объема существующих прав и свобод, обеспечения права каждого на достаточный жизненный уровень для себя и своей семьи.

Ключевые слова: социальная защита, право на социальную защиту, ветераны войны, сужение объема прав и свобод.

Tarasenko V. Problems of ensuring of appropriate social protection of veterans of war

Summary. The article is dedicated to the investigation of the legislation that establishes the alteration of the mechanism for the implementation of the right of veterans of the war. The correspondence of these provisions to the Constitutional Propositions of Ukraine and to the Judgements of the Constitutional Court of Ukraine concerning non-allowability of entering of arbitrary alterations to the existing system of norms, concerning non-admission of narrowing of content and scope of existing rights and freedoms, concerning ensuring of the right for each person for the appropriate living standard for himself and for his family is analyzed.

Key words: social protection, right for social protection, veterans of the war, narrowing of the scope of rights and freedoms. 